\title{
The Peace-Building Process in the South China Sea: Challenges and Future Prospects for a Maritime Regime
}

\section{Abstract}

The aim of this article is to examine two treaties which are often presented by scholars as potential models for a maritime regime in the South China Sea, namely the Svalbard Treaty and the Antarctic Treaty System. The work concludes that even though both of the treaties have resolved equally complex territorial disputes, their importance as a role model for the SCS is limited due to the unique political condition in the Asia-Pacific. However, the solutions within the sphere of environmental protection and the structure of decision-making institutions developed by the abovementioned treaties present a valuable lesson and a potential example for the countries involved in the South China Sea dispute to emulate. The article argues that cooperation within environmental protection and fisheries management, as a low-profile endeavour, is easier to be put into practice than the joint development of highly contested hydrocarbon resources of the SCS. Furthermore, it can potentially lay foundation for the future high profile collaboration. The paper also presents a model of a maritime regime for the South China Sea.

Keywords: South China Sea, environmental cooperation, maritime regime, Antarctic Treaty, Svalbard Treaty 


\section{Процесс миростроительства в Южно-Китайском море: вызовы и перспективы морского режима}

\section{Аннотация}

Целью данной статьи является изучение двух договоров, которые часто представляются учеными в качестве потенциальных моделей морского режима в Южно-Китайском море, а именно Договора о Шпицбергене и Системы Договора об Антарктике. В работе делается вывод о том, что хотя оба договора разрешили одинаково сложные территориальные споры, их важность в качестве образца для подражания для СКС ограничена из-за уникальных политических условий в Азиатско-Тихоокеанском регионе. Однако решения в области защиты окружающей среды и структуры институтов принятия решений, разработанные в рамках вышеупомянутых договоров, представляют собой ценный урок и потенциальный пример для подражания странам, вовлеченным в спор вокруг Южно-Китайского моря. В статье утверждается, что сотрудничество в области охраны окружающей среды и управления рыболовством, как скромное мероприятие, легче реализовать на практике, чем совместная разработка весьма спорных углеводородных ресурсов Южно-Китайского моря. Более того, это потенциально может заложить основу для будущего сотрудничества на высоком уровне. В статье также представлена модель морского режима Южно-Китайского моря.

Ключевые слова: Южно-Китайское море, сотрудничество в области окружающей среды, морской режим, Договор об Антарктике, Договор о Шпицбергене

\section{Introduction}

7 he South China Sea (SCS) is currently the topic of heated debates among 1 both academics and policy makers in the region of Asia-Pacific and beyond. It is worth mentioning that it is considered to be one of the most problematic waters on the international arena. Due to complex territorial disputes, high significance of the region for the international economy, as well as the growing tension between the U.S. and China, the SCS has been perceived as Asia's potential military flashpoint since the 1990s (Buszyński, 2012; Turcsanyi, 2018). Still, certain scholars have pointed out that although territorial issues have not been resolved, predictions concerning a military conflict have been premature (Weissmann, 2012). Regardless of whether the South China Sea disputes lead to a full-scale military confrontation or not, not only does this constantly simmering conflict negatively influence diplomatic relations between the major regional powers, namely China and 
the U.S., as well as between China and other claimants, but also hinders cooperation in several aspects in the field of the human security, such as food and environment (Kraska, 2019). For this reason, scholars have been trying to develop a maritime regime allowing for effective conflict management (Valencia, Van Dyke and Ludwig, 1999; Buszynski and Sazlan, 2007; Beckman, 2009). Nevertheless, the efforts to contain the conflict have been unsuccessful so far.

The aim of this article is to present a model of an institution focused on the conservation and management of fishery and environment of the South China Sea that is partly based on solutions implemented by the Svalbard Treaty and the Antarctic Treaty. Both of the treaties are frequently depicted as instances of settlement of long-lasting, multinational and complex territorial disputes successfully controlling the level of tension between the claimants. Even though not every solution effective in the case of the Svalbard Islands or Antarctica would be suitable for the South China Sea, some of the ideas concerning environmental conservation and the organisation of institutions governing the disputed areas may become an inspiration for the states of the Southeast Asia. The proposed model is not the ultimate solution for the territorial disputes of the South China Sea. Instead, it ought to be rather perceived as a means for the management of the dispute that may pave the way towards a high-profile collaboration in the future, such as the joint development of hydrocarbon resources.

\section{Background}

The South China Sea is a semi-enclosed sea (Zhang, 2019) defined in article 122 of the United Nations Convention on the Law of the Sea (1982) (henceforth referred to as UNCLOS) as "a gulf, basin or sea surrounded by two or more States and connected to another sea or the ocean by a narrow outlet or consisting entirely or primarily of the territorial seas and exclusive economic zones of two or more coastal States." It covers the area of 3.625 million km² (Mitchell, 2016) and comprises mainly Exclusive Economic Zones (EEZ) of China, Taiwan, The Philippines, Brunei, Malaysia, Singapore, Indonesia, Thailand and Vietnam (Zhang, 2019). In the northeast, the Luzon Strait connects the South China Sea with the Pacific Ocean, whereas the Taiwan 
Strait links it with the East China Sea. In the south, the South China Sea also communicates with the Sulu Sea via the Balabac and Mindoro Straits, as well as the Andaman Sea and the Java Sea via the Sunda Shelf (Wang, Cui and Zhang, 2009).

Due to its specific geographic, political and ecological features, semi-enclosed seas are more exposed to threats and conflicts due to navigation issues, the growing level of pollution, the exhaustion of maritime resources (Zhang, 2019), as well as the possibility of overlapping maritime zones. The South China Sea is particularly known worldwide for the last of the abovementioned reasons owing to multiple territorial conflicts (Weissman, 2012). The South China Sea has been haunted by four major territorial disputes over several groups of islands. The first one concerns the Paracel Islands located 120 nautical miles from the Ly Son Island of Vietnam and encompassing the Amphitrite Group in the northeast and the Crescent Group in the west ( $\mathrm{Vu}$, 2014). China, Taiwan and Vietnam lay their claims to this archipelago; yet, China has been occupying it since 1974 (Pietrasiak, 2016). Another conflict centres around the Scarborough Shoal in the eastern part of the South China Sea. Although it is claimed only by two states, China and the Philippines (Peace Palace Library, n.d.), the Shoal has drawn attention of the media worldwide because of the arbitration case (No. 2013-19) initiated by the latter country in 2013 (Chansoria and Palma-Robles, 2015). On 12 ${ }^{\text {th }}$ July, 2016, the arbitration ruling declared that the Chinese claims related to the Philippine EEZ were invalid, whereas the Scarborough Shoal was deemed as a "rock" not entitled to generate EEZ or continental shelf provided by the UNCLOS (The Philippines v. The People's Republic of China, 2016, para. 643). The third issue is devoted to the Natuna Islands, which Indonesia possesses sovereign rights to. Despite the fact that China does not lay its claims to the islands, its EEZ overlaps with the so-called the U-shaped line, also known as the Nine-Dash Line that for the first time appeared on a map published by the Republic of China (ROC) in 1947 and encircles approximately 90 percent of the entire South China Sea (Huang and Jagtiani, 2015).The fourth and the last problem focuses on the Spratly Islands and is considered to be the most complex dispute of the South China Sea due to the fact that as many as six countries, namely China, Taiwan, Vietnam, Malaysia, Brunei and the Philippines, claim their rights to the archipelago (Pietrasiak, 2016). 
Although the disputes over the Spratly Islands as well as other archipelagos center around territorial claims, in this context, it is to be underlined that control over those islands would give the owner a dominant position in the region for a few reasons. Firstly, the South China Sea is one of the most essential and busiest trade routes, through which thousands of vessels transit daily connecting the Middle East and the East Asia. The value of the annual trade amounts to approximately USD 5,3 trillion. Secondly, the seabed of the South China Sea contains the deposits of gas and oil. According to the Energy Information Agency, around 190 trillion cubic feet (Tcf) of natural gas and 11 billion barrels (bbl) of crude oil reserves can be found there. Moreover, the U.S. Geological Survey estimates that the seabed in the area of the Spratly Islands may contain between 7,6 and 55,1 Tcf of natural gas and between 0,8 and 5,4 billion bbl of oil of undiscovered reserves (U.S. Energy Information Agency, 2013). Last but not least, the South China Sea is one of the richest fishing grounds in the world. The regional market constitutes approximately 12 percent of the global catches worth around USD 22 billion. Additionally, more than 3.7 million people are employed in the fishery industry in the Southeast Asia. In other words, the ownership of the contested islands of the South China Sea would provide the claimants with access to new gas and oil grounds, more fishing grounds, and the ability to control shipping lanes (Zhong and White, 2017).

In spite of the fact that little chances exist for the settlement of any of the abovementioned disputes, various academics have been trying to find a suitable resolution that would enable turning hostility and mistrust between the claimants into cooperation, stability and prosperity. One of the proposed models for dispute management receiving most attention from the academic circles is the joint development focusing on the exploitation of hydrocarbons (Zou, 2006; Buszynski and Sazlan, 2007; Beckman et al., 2013; Meierding, 2017). In 2005, the national oil companies from the Philippines, China and Vietnam even engaged in the Joint Marine Seismic Undertaking (JMSU), which was back then perceived as a possibility for a breakthrough. However, in 2008, JMSU came to an end in the atmosphere of a scandal associated with corrupt practices interlinked with the Chinese overseas development aid and violation of the Philippine constitution (Storey, 2008). 
Except for the joint development of hydrocarbons, some academics (Kao, Pearre and Firestone, 2012; Nguyen, 2012; Zhang, 2018; Kao and Pearre, 2018) drew their attention to the possibility of cooperation in terms of fishery management and conservation. Contrary to oil and gas exploitation, fishery has been perceived as both less controversial and costly area fostering cooperation between the claimants and may serve as a confidence-building measure between the involved entities aiming at decreasing tension in the region. Moreover, overfishing and illegal fishing have become one of the major issues threatening the food security of the Southeast Asia, where approximately 77 percent of people depend on pelagic fishery as their main source of daily proteins. Furthermore, not only is illegal, unreported and unregulated (IIU) fishing the cause of fish stock depletion, but also it is associated with various crimes, including smuggling and slavery (Zhang, 2018).

The littoral states of the Southeast Asia have tried to address the problem of IIU fishing and environmental damage by establishing various forms of cooperation. At the international level, institutions, such as the Asia-Pacific Fishery Commission (APFIC), the East Asian Sea Regional Seas Programme, the Partnership in Environmental Management for the Seas of East Asia and the Southeast Asian Fisheries Development Center (SEAFDEC) were established (Kao, Pearre and Firestone, 2012; Zhang, 2018). Attempts at managing fisheries have also been undertaken at the bilateral, the Gulf of Tonkin Fishery Agreement signed by China and Vietnam, being the foremost example (Zhang, 2018).

Despite the fact that cooperation concerning marine environment management and protection has been commenced at the multilateral level, the abovementioned institutions have only partly fulfilled their purposes due to a few common weaknesses, for instance, voluntary membership, either too broad or narrow geographical scope, as well as overlapping goals and undertakings (Kao, Pearre and Firestone, 2012). For those reasons, the claimants engaged in the territorial disputes in the South China Sea should establish an institution serving as a regional center for environment conservation, collecting data about fish population, setting the level of catches per species, establishing protected areas, and monitoring fishing vessels in the South China Sea. 


\section{The Svalbard Treaty}

The Svalbard Islands, discovered by Willem Barentsz in 1596, constitute a group of isles in the Arctic Ocean, between Norway and Greenland. For many years, the archipelago was considered to be terra nullius in the light of international law (Ohnesorge, 2016). The discovery of vast deposits of mineral and coal in the $19^{\text {th }}$ century led several countries to competition over the islands. Nevertheless, coal is not the only factor attracting the attention of the states involved in the dispute. The Svalbard Islands, especially the southeasters continental shelf, demonstrate a potential for new hydrocarbon discoveries. The adjacent waters of the archipelago, the Barents Sea in the west in particular, abound in fish. Furthermore, the archipelago's location is not without the geopolitical value, since waters between the shores of the Svalbard Islands and Norway do not freeze and are in close vicinity of crucial sea lanes (Valencia, Van Dyke and Ludwig, 1999), which only increases the appetite for the archipelago among the competitors.

The Svalbard Treaty ${ }^{1}$ was signed on $9^{\text {th }}$ February, 1920, by Australia, Canada, Denmark, France, Italy, Japan, the Netherlands, Norway, Sweden, the United Kingdom, and the United States. The Soviet Union and Germany joined the treaty in 1924 and in 1925 respectively. According to this treaty (1920, art. 1), Norway was granted full sovereignty over the archipelago and is responsible for ratification and enforcement of the legislation. Notwithstanding this, the Svalbard Treaty (1920, art. 8) states that Norway may use incomes from taxes only to supply the budget of the Svalbard Islands and the taxes themselves are supposed to be set at the level required only for the administration of the Islands. In terms of the exploitation of resources, living and non-living, as well as conduct of any maritime, industrial and mining undertakings, signatories enjoy equal rights (The Svalbard Treaty, 1920 , art. 3). In addition to the unique solution of the question of sovereignty, among regulations stipulated by the treaty that should not go unnoticed are articles 2 and 9 (The Svalbard Treaty, 1920). According to the former, Norway

1 Officially, the treaty is called Treaty between Norway, the United States of America, Denmark, France, Italy, Japan, the Netherlands, Great Britain and Ireland and the British overseas Dominions and Sweden concerning Spitsbergen. Retrieved from: http://library.arcticportal.org/1909/1/The_Svalbard_Treaty_9ssFy.pdf. 
possesses an exclusive right to establish rules aiming at environmental preservation on land and at sea. The latter imposes a ban on any kind of military usage of the Islands.

The most prominent novelty provided by this treaty is the manner it dealt with sovereign rights through granting them solely to one claimant, who in return is liable for administering the area. Still, in the case of the Spratly Islands, such solution would not serve its purpose because this archipelago, contrary to the Svalbard Islands, has never been exclusively dominated only by one state (Valencia, Van Dyke and Ludwig, 1999). Some of the claimants, e.g. China and Vietnam, give priority to sovereignty and territorial integrity, and therefore, giving up their own claims to a sovereign right over the archipelago in favour of just one claimant for the sake of stability would not meet with applause of their citizens. Besides, the argumentation concerning sovereignty over the Spratly Islands of every claimant is not free from flaws. Hence, the question on who is supposed to possess the sovereign right over the Spratly Islands cannot be answered unequivocally. It is understandable that China, while demonstrating the largest economic and military potential, would pretend to gain the rights over the Spratly Islands. However, this solution would undoubtedly meet with Vietnam's opposition, as Vietnam claims the entire Spratly archipelago as well and China's sovereignty would undermine its position in the region. The remaining claimants would also take exception to granting China full sovereignty on the grounds that Beijing's already assertive behaviour threatens their interests in the region, whereas putting China in the position of a sovereign would probably limit their influence in the South China Sea to even greater extend. Hence, Mark J. Valencia, Jon M. Van Dyke and Noel A. Ludwig (1999) proposed a solution inspired by the Svalbard treaty in which they suggested creating a Spratly Management Authority, where China would be given a permission to prevail. This approach would constitute the middle ground between granting sovereign rights exclusively to one state and forcing China, the most influential of the claimants, to compromise its national interests in the South China Sea. Beijing has emphasised on multiply occasions that the Spratly Islands are "an inherent part of China's territory" (Mission of the People's Republic of China to the European Union, 2016). Thus, every solution involving the division of sovereignty is doomed to fail 
from the very onset. H. W. Ohnesorge (2016), however, advocates an idea of establishing a "South China Sea Exploration Company", in which every claimant would have its own representative selected from oil companies. The South China Sea Exploration Company would possess the authority to grant companies exploitation right of hydrocarbons. As Ohnesorge (2016) argues, such approach would provide states with a model of joint development of the contested waters without the necessity of deciding upon a sovereign right, an issue which has already proven to be the main reason for the stalemate in improving relations between littoral countries of the South China Sea.

In other aspects, for instance environmental protection and upholding peace in the region, the Svalbard Treaty constitutes an example to look up to and is worth consideration. Following the article 9 (The Svalbard Treaty, 1920), Norway is prohibited from creating any naval bases and any facilities of the military use. In the case of the Svalbard Islands, this provision contributed to building the regional stability and managing tension in the geopolitically prominent region. Yet, considering the fact that except from Brunei, all claimants have set garrisons on the islands they occupy and engaged in building military facilities (Asia Maritime Transparency Initiative, n.d.), calls for the demilitarization of the area would certainly prove to be fruitless. The scenario proposed by Mark J. Valencia, Jon M. Van Dyke and Noel A. Ludwig (1999) to transform these facilities into objects of the scientific and economic uses also seems to be unlikely to be implemented. H.W. Ohnesorge (2016) suggests that the claimants could agree to halt further militarization and pledge to use the Spratly archipelago only for peaceful purposes. Curtailing the military build-up in the region is of great salience to managing tension in the region, where in the recent years, vast Chinese land reclamation could be witnessed (Asia Maritime Transparency Initiative, n.d.). Aside from that, the instalment of military facilities on artificial islands threatens that clashes between fishing vessels followed up by the intervention of Coast Guard ships and the modernization of armies could occur. Even though limiting military activities in the South China Sea has reduced prospects for being put into practice, some forms of closer military cooperation at different levels, such as joint patrols, combating piracy and joint maritime emergency drills could be used as confidence building measures between parties involved in the Spratly Islands dispute. 
In terms of environmental protection, the Spratly Islands contesters have much to learn from the Svalbard Treaty. Nonetheless, its provisions and solutions should be treated as an inspiration rather than a model to emulate. According to article 2 (The Svalbard Treaty, 1920), Norway, as a sovereign, was put in charge of environmental protection and is allowed to "take or decree suitable measures to ensure the preservation and, if necessary, the reconstitution of the fauna and flora of the said regions, and their territorial waters". In the light of this provision, Norway has the right to undertake any measures aiming at environmental protection and conservation. Under such legal circumstances, the Svalbard Environmental Protection Act was introduced in 2001. The Act (2001) addresses a wide range of issues, including species management, waste disposal, dumping and incinerating waste from ships, species management, land use plans, technology usage, protected areas, harvesting, as well as protecting cultural environments and cultural heritage. The environmental protection has been given the upmost priority and as section 8 of chapter II (Svalbard Environmental Protection Act, 2001) states, all undertakings conducted within the Svalbard Archipelago will be assessed in view of their impact on the environment and cultural heritage. Any person responsible for initiating activities threating to cause damage to the environment should be charged with bearing the costs of limiting or preventing damage (Svalbard Environmental Protection Act, 2001, chap. II, sec. 9). The Act (2001, chap. II, sec. 10) also imposes the use of technology causing the least damage to the ecosystems with the exception of economic enterprises already under way that require specific machinery to be carried out. The Svalbard Environmental Protection Act (2001, chap. III, sec. 16) established two forms of the natural habitat protection: the national parks and nature reserves. Currently, approximately 65 percent of the land of the archipelago and 84 percent of the adjacent waters are covered by the national parks or nature reserves (Governor of Svalbard, n.d.). All of species of flora and fauna are under protection, excluding only animals that do not return to the Svalbard Islands in order to breed (Svalbard Environmental Protection Act, 2001, chap. IV, sec. 23). Harvesting fauna is only allowed to individuals possessing a hunting or fishing licence. Moreover, only species prescribed by the Ministry of Climate and Environment of Norway are suitable for harvesting during specified periods (Svalbard Environmental Protection Act, 2001, chap. III, sec. 31). 
With regard to fishery regulations and management, the Svalbard Treaty also presents solutions that may become an inspiration for establishing a set of rules for the South China Sea. In 1977, Norway created the Fishery Protection Zone (FPZ) reaching $200 \mathrm{~nm}$ from the coastline of the archipelago, instead of its own Exclusive Economic Zone. Due to the border agreement with Russia, the FPZ was readjusted and at the current state, it owns the area of $715000 \mathrm{~km}^{2}$. In order to operate within the FPZ, fishing boats have to adjust to a rage of technical regulations, the aim of which is to protect fish populations, such as the minimum mesh size and sorting grids. Moreover, dumping the unwanted fish catch not complying with the size regulations is prohibited (Misund et al., 2016).

To prevent overfishing and illegal harvesting, the Joint Norwegian-Russian Fishery Commission, in consultation with the International Council for the Exploration of the Sea (ICES), sets the fishing quotas for each species. While the Norwegian Coast Guard regularly patrols the waters of FPZ to ensure that all the restrictions are met, the Directorate of Fisheries of Norway collects the detailed data concerning the operations of Norwegian fishing vessels and publishes statistics about the weight and monetary value of catch of every species. The Directorate's website made available to the public a complete database containing the collected information from 2000 until the present. Furthermore, since 2003, all Norwegian fishing boats the size of which exceeds 15 meters are obliged to carry a satellite transmitter allowing Fisheries Monitoring Centre at the Norwegian Directorate of Fisheries to track the movements and the speed of a given vessel (Misund et al., 2016).

Examples of undertakings aiming at the preservation of the fragile environment of the Svalbard Islands in its almost impeccable form can be multiplied. Still, it is to be underlined that joint efforts to protect the maritime environment in the South China Sea are necessary if the littoral states do not wish to witness a catastrophe caused by overfishing. Despite several fishery management regimes implemented by the South China Sea countries, the lack of coordination among the governments in case of the implementation of measures concerning fish resources protection is one of the main reasons, why these regimes leave much to be desired (Naess, 2001; Kao, Pearre and Firestone, 2012; Van Dyke and Broder, 2014). If any kind of the maritime regime is going to be enforced, joint activities aiming at the preservation 
of living resources and the ecosystems of the Spratly Islands and the South China Sea as such will be essential.

\section{The Antarctic Treaty}

The Antarctic treaty is frequently depicted as an exemplary solution for the dispute over the South China Sea due to the multiple number of claimants with overlapping claims participating in the dispute over Antarctica and the treaty's longevity (Valencia, van Dyke and Ludwig, 1999; Zou, 2014; MacLaughlin and Nasu, 2015; Scott, 2018). Contrary to the Svalbard Treaty that presents solutions in terms of environmental protection and regulation enforcement more suitable to the South China Sea, the greatest value of the Antarctic Treaty lies in the organisation of its institutions and the decision-making process. The treaty was reached in Washington, on $1^{\text {st }}$ December, 1959, by 12 founder states called the Antarctic Treaty Consultative Parties that were active in Antarctica during the International Geophysical Year of 1957-58, namely the United Kingdom, Australia, France, New Zealand, Norway, Chile, and Argentina, which had territorial claims in Antarctica, as well as Australia, Belgium, Japan, the US, Russia (back then the USSR) and South Africa, who wished to pursue their interests there. In 1983, other states were allowed to accede to the treaty and ever since, the number of the signatories has grown up to 52. On the basis of conducting the scientific research in Antarctica, 28 of them acquired the status of a Consultative Party and gained the right to vote during the Antarctic Treaty Consultative Meetings (ATCM). Since 1961, when the first proceedings of ATCM took place, the provisions of the treaty were enriched by several agreements and recommendations reshaping the treaty from being a single agreement into the system aiming at coordinating the undertakings of parties (Valencia, van Dyke and Ludwig, 1999).

Article 4 (The Antarctic Treaty, 1959), which is the core of the entire treaty, provides a salient example for the South China Sea claimants, for it sets aside all territorial disputes. All of the signatory states possessing any claims to Antarctica gave up pursuing their rights to it until the treaty is in force. Additionally, no new claims or enlargements of the existing claims can be made. Such solution is more realistic to be put into practice in the case of 
the South China Sea than resolving the dispute and granting the sovereign right solely to one state, just as it happened on the Svalbard Islands.

The treaty imposes an obligation to settle disputes and disagreements peacefully. In case any dispute arises, the involved parties are supposed to consult one another, whether the dispute should be resolved via "negotiation, inquiry, mediation, conciliation, arbitration, judicial settlement or other peaceful means of their own choice" (The Antarctic Treaty, 1959, art. 11). If efforts of the parties prove fruitless, the parties should turn to the International Court of Justice for resolution (The Antarctic Treaty, 1959, art. 11). The treaty leaves room for various approaches towards dispute settlement, which seems to be well tailored to the South China Sea dispute, since the preferences of the claimants vary from bilateral and multilateral negotiations to judicial settlements.

Over the years, the Antarctic Treaty has been transformed from a single agreement into the system of mutually complementary conventions and the net of advisory bodies. Therefore, the treaty is commonly referred to as the Antarctic Treaty System (Valencia, van Dyke and Ludwig, 1999). It is worth outlining the treaty's institutions and supportive agreements in order to gain the better understanding of how this unique worldwide agreement works and how it can contribute to the creation of the relevant system in the Spratly Islands.

The Antarctic Treaty Consultative Meetings is a special decision-making group issuing special policies called "recommendations" and taking care of such matters as the scientific research, environment protection, tourism management, the preservation of historic sites, as well as gathering and exchanging information on various subjects, including meteorological, hydrographical data, and logistics (Handbook of the Antarctic Treaty System, 2002). The proceedings of ATCM are always accompanied by a meeting of the Committee for Environmental Protection (CEP) which is the advisory body established by the Environment Protocol in 1998, aiming at providing support to the ATCM related to the implementation of the Protocol. Except for the representatives of parties, experts in relevant fields of studies are often invited to attend the meetings as observers (Secretariat of the Antarctic Treaty, n.d.). A potential regime for the Spratly Islands will require an administrative body, in which the claimants would be able to make decisions about the most vital matters, such 
as security, hydrocarbon exploitation and environmental protection. Over the years, more specialised institutions have been established in order to facilitate the functioning of the Antarctic Treaty System, for instance the Scientific Committee on Antarctic Research (SCAR) and the Council of Managers of National Antarctic Programs (CONMAP). The former is concerned with the coordination of international scientific research, whereas the latter serves as the forum, where operational problems are addressed and the work of Standing Committee on Antarctic Logistics and Operations is supervised (Handbook of the Antarctic Treaty System, 2002).

Except for an extensive net of organizations, the Antarctic Treaty System comprises several conventions supplementing the treaty with the provisions concerning environmental protection. Introduced in 1962, Agreed Measures for the Conservation of Antarctic Fauna and Flora were the first step taken by ATCM towards a complex system of provisions guarding primordial nature of Antarctica (Valencia, van Dyke and Ludwig, 1999). Article 4 (Agreed Measures for the Conservation of Antarctic Fauna and Flora, 1962) established "specially protected species" and "specially protected areas" to limit the human's harmful influence on the local animals and plants. Hunting and killing animals requires a permit that will be granted only under specific circumstances listed in the contents of article 6 (Agreed Measures for the Conservation of Antarctic Fauna and Flora, 1962) and including the scientific research, providing the amounts of food for people and dogs allowing survival and delivering specimens for museums and scientific institutes.

Another agreement, that is Convention for the Conservation of Antarctic Seals (1972, art. 1 and 2) prohibits killing specified species within the designated area of the seas south $60^{\circ}$ South Latitude, establishes special "seal reserves", defines when "sealing zones" shall be closed and apportions the total number of permitted catches (Convention for the Conservation of Antarctic Seals, Annex, 1972). This Convention is also vital from the point of view of the decision-making process, as only two-thirds of votes are necessary to make changes to annexes, though the decision, whether a new party can join the Convention must be taken unanimously (Valencia, van Dyke and Ludwig, 1999).

The Convention on the Conservation of Antarctic Marine Living Resources signed in 1980 outstands in various aspects. It allows NGOs and 
international organisations to become a signatory party. In terms of the decision-making process, it introduces making decisions by simple majority in cases not considered as matters of substance (Convention on the Conservation of Antarctic Marine Living Resources, 1980, art. 12). It is distinctive from the point of view of its attitude towards conservation itself, since it presents the ecosystem approach (Valencia, van Dyke and Ludwig, 1999).

Protocol on Environmental Protection to the Antarctic Treaty adopted in 1991, further develops environmental protection, which became the most essential component of the Antarctic Treaty. Of the greatest significance is article 7 of the Protocol (1991) allowing for the exploitation of natural resources only for scientific purposes; commercial exploitation has been banned for 50 years.

One of the most engaging management systems is included in the Convention on the Regulation of Antarctic Mineral Resource Activities, even though it has never been put into force. Had the Convention been implemented, it would have established two administrative bodies, namely Scientific, Technical and Environmental Advisory Committee and Antarctic Mineral Resources Commission. The latter would be the main decision-making body in terms of supervising the implementation of the Convention's provisions, scientific research, the collection of scientific and technical information, and the designation of zones in Antarctica, where the exploitation of minerals is banned. It would have encompassed Consultative Parties and other entities involved in research and the sponsorship of resource development in Antarctica. Decisions in matters of substance would be made by three-fourth majority, whereas in such matters as setting the budget, the accession of new members or appointment of zones for possible exploitation of resources consensus would be needed. The role of the former would have been to advice the parties regarding the formulation of adequate environmental, technical and science policies. Each member would have been represented by one delegate with a substantial environmental, scientific or, technical expertise. The observer status would have been given to any signatory of the Antarctic Treaty or the Convention on the Conservation of Antarctic Marine Living Resources who would not be a party of the Convention on the Regulation of Antarctic Mineral Resource Activities (Handbook of the Antarctic Treaty System, 2002). 
As the abovementioned administrative bodies and agreements show, the South China Sea claimants have a lot to learn from the Antarctic Treaty System in terms of managing the contested areas and environment protection. However, it should be underlined that while creating a model of cooperation for the South China Sea, the Antarctic Treaty ought not to be followed to the letter because some of its provisions and solutions are not tailored to the South China Sea's conditions. The system of unannounced visits would not contribute to stabilising the region; on the contrary, it might even rise tension, since some claimants would consider it as a form of intrusion into their operations in the South China Sea and a provocation that could jeopardize the effectiveness of cooperation. Moreover, strict provisions of environmental protection, such as the ban on hunting for purposes different than scientific research and the survival of people are also not applicable in the SCS, where fishery is one of the key industries of economies of the countries in the region.

Yet, following the example of the Convention on the Regulation of Antarctic Mineral Resource Activities, the claimants of the South China Sea could establish a commission, the aim of which would be making decisions concerning the scientific research, tourism management, the establishment of environmental protection zones, catch quotas, gathering and publishing databases, as well as regulating enforcement measures. It could comprise the claimant states and members of ASEAN due to the importance of the South China Sea's living resources for the economies of all littoral countries in the region.

\section{The Model of Maritime Regime for the South China Sea}

Following the example of the Svalbard Treaty (1920), the countries of the South China Sea could establish a jointly monitored and protected area resembling the Fishery Protection Zone in order to both gain greater control over the catch size and undertake more effective actions aiming at preventing further depletion of various fish species' populations. Several islets within the area, chosen due to their value for the scientific research, ecotourism and recovery of species, could be transformed into marine parks. Not only would such areas cover the islands themselves, but also the reefs and waters 
up to $12 \mathrm{~nm}$ (Valencia, Van Dyke and Ludwig, 1999). Examples of similar joint maritime protection areas can be found within the region of the Southeast Asia. In 1996, Malaysia and the Philippines signed a Memorandum of Agreement establishing Turtle Islands Heritage Protected Area in the Sulu Sea. Three years later, the involved parties introduced Turtle Islands Wildlife Sanctuary and declared as Extremely High (EH) for upholding and protecting biodiversity. It is the first transboundary sea turtle protection area in the world (UNESCO, n.d.) and the only rookery of green sea turtles located in the Southeast Asia (ASEAN Centre for Biodiversity, 2010). Another option proposed by Mark J. Valencia, Jon M. Van Dyke and Noel A. Ludwig (1999) is establishing a multiuse system dividing the area into three levels of protection. Selected territories and waters could be closed for the commercial use and solely dedicated to the scientific research due to their biodiversity and significance for survival of various species. The second would include areas ecologically valuable and opened for tourism, whereas the third one would allow commercial fishery.

The management of fisheries and environmental protection areas could be entrusted to an institution established solely for this purpose (henceforth referred to as the South China Sea Committee). Such institution could work under the aegis of ASEAN (The Association of Southeast Asian Nations), since not only is the preservation of living resources of the South China Sea in the interest of the parties engaged in the dispute, but also all littoral countries of the region. The scope of this area is expected to be precisely delimited and it should include waters particularly significant from the point of view of commercial fishing, scientific research, as well as the recovery of species. Such institution could be modelled after the Joint Norwegian-Russian Fishery Commission, or Antarctic Mineral Resources Commission. However, it is worth mentioning that relevant examples of organisations can also be found in the Southeast Asia. China and Vietnam created the Joint Fishery Committee (JFC), the goal of which is to coordinate fisheries research, decide upon recommendations regarding fishing quotas within the joint Chinese-Vietnamese fishing zone in the Gulf of Tonkin, as well as communicate with the representatives of the fishery industry. Moreover, China and Vietnam reached agreement concerning the delimitation of the national and mutual jurisdiction zones (Dutton, 2011). Likewise, the 
claimants of the Spratly Islands could establish a similar institution that would be put in charge of making decisions related to the scientific research, stock assessment, the delimitation of environmental protection zones, the coordination of the levels of catches, the scientific research and databases, tourism management, as well as the establishment of regulation enforcement measures.

Similarly to the Convention on the Regulation of Antarctic Mineral Resource Activities (1988), the claimants could establish an advisory body consisting of specialists in relevant fields appointed by each member, which would provide science-based recommendations to the member states of the South China Sea committee concerning the size of the allowed catch of each species, the location of the protected areas, the number of tourists visiting marine parks, etc. In order to provide the committee members with the most comprehensive opinions, the states involved in the dispute could draw on the example of the Convention on the Conservation of Antarctic Marine Living Resources (1980) and allow NGOs and international organisations tackling with environmental protection to join the advisory institution. Determining possible forms of participation for other institutions is of the utmost importance, since such institutions may prove to be invaluable in terms of providing advice for the functional organisation and management of multiple aspects a potential organisation covering the South China Sea would have to deal with.

Another model of an institution suitable for fishery and environmental management can be provided by Regional Fisheries Management Organisations (RFMO) established under the aegis of the Food and Agriculture Organisation of the United Nations (FAO). Following the example of the Mediterranean Sea, the Caribbean Sea, as well as the West and Central Pacific Ocean, the states of the Southeast Asia could also establish their own RFMO that would serve as the regional mechanism for environment and fishery management and provide the claimants with a dispute settlement mechanism (Kao, 2015). The establishment of RFMO was advocated by Arif Havas Oegroseno, the deputy Coordinating Minister of Maritime Affairs and Resources of Indonesia, who attributed the lack of the sufficient data concerning fishery depletion to the fact that the countries from the South China Sea region still have not founded a RFMO (Zhang, 2018). In his 
study, Pakjuta Khemakorn (2006) underlines the importance of RFMO as a particularly significant form of managing straddling and highly migratory fishery. Moreover, RFMO may support the littoral countries in lowering the costs of stock conservation and research.

Another option is establishing a subcommittee of the already existing RFMO set for the Pacific Ocean, namely the Commission for Conservation and Management of Highly Migratory Fish Stock in the Western and Central Pacific Ocean, also called Western and Central Pacific Fisheries Commission (WCPFC). Nonetheless, there are a few obstacles making the implementation of this solution tougher than setting up a new RFMO. Firstly, not every claimant state of the South China Sea belongs to WCPFC and therefore, Vietnam and Malaysia would have to become members of WCPFC at first. Secondly, the WCPFC's authority is focused on highly migratory species, rather than all marine living resources (Kao, 2015).

Except for the shape of a potential institution managing environmental conservation and fishery in the South China Sea, another issue that needs to be addressed is the enforcement of regulations established by the South China Sea committee. As it was demonstrated by the arbitration case ruling between the Philippines and China, law enforcement is one of the most salient weaknesses of the international law. Asia Maritime Transparency Initiative published a "Blueprint for Fisheries Management and Environmental Cooperation in the South China Sea" (2017), in which it proposes several solutions to tackle this problem. Firstly, the member states of the South China Sea Committee could split the responsibility for monitoring fishing vessels among themselves. The area which each country would supervise should consist of $20 \mathrm{~nm}$ from the features in the disputed area, as well as up to $200 \mathrm{~nm}$ from their coastlines. In case of overlapping areas, the $20 \mathrm{~nm}$ zones would take precedence. If more than two areas are overlapping, the median line ought to be delimited in order to separate the responsibility zone of each country. In this context, it needs to be underlined that none of the abovementioned zones would be equal to maritime boundaries and thus, such zone would not be treated as the acknowledged EEZ or territorial sea, within which states have sovereign rights. Secondly, the member states should issue licences for domestic and foreign fishing vessels within their zones in accordance with the regulations accepted by the South China Sea Committee. Thirdly, the areas 
beyond the responsibility zones could be patrolled by any member state yet, joint patrols would be recommended. Last but not least, the judgement and punishment of fishing crews violating the regulations established by the South China Sea Committee should be within the scope of duties of the flag state. Apart from that, the arresting member state is supposed to arrange the transportation of the crew and their vessel. Certain solutions put forward by the Asia Maritime Transparency Initiative (2017), such as the delimitation of responsibility zones within the features already occupied, seem to be reasonable and pragmatic, since none of the claimants would ever agree to abandon the isles they settle. Nonetheless, the $200 \mathrm{~nm}$ zone would resemble the EEZ, even though Asia Maritime Transparency Initiative underlined that such zones would not be regarded as EEZ, or any other maritime zone provided by the UNCLOS. For this reason, such division would still create tension and objection from some of the claimants. Nevertheless, joint patrols, the treatment of vessels violating the law and fishing licence issuance are more likely to be implemented successfully and contribute to the confidence-building process, should any institution governing the resources and environmental conservation of the South China Sea be ever established.

Asia Maritime Transparency Initiative (2017) also addressed the matter of dispute resolution that may arise due to the differences in the interpretation of regulations introduced by the South China Sea Committee. In accordance with the blueprint, the member states should choose up to four experts to serve as their representatives in a commission of mediation, inquiry, or conciliation, which would be established whenever necessary. However, before the establishment of such commission, the conflicting parties ought to attempt to resolve the dispute through negotiations. Only after failure in this situation, should the parties request the South China Sea Committee to a relevant commission. The commission will give the parties its recommendation concerning the settlement of the dispute. The emphasis on proceeding with the negotiations first and pointing out to other methods of conflict resolution as the last resort may prove to be more acceptable for the claimants, especially for China, which is known for its preference to resolve conflictual issues bilaterally.

While discussing any possible model of cooperation for the claimants of the Spratly Islands, including the matter of the decision-making procedure, 
the engagement of states outside the region and the participation of Taiwan needs to be taken into account. Firstly, it has to be underlined that the choice of the decision-making procedure will determine the effectiveness and, in consequence, the survival of the South China Sea Committee. The Convention on the Regulation of Antarctic Mineral Resource Activities (1988) assumed that the matters of substance ought to be decided by a three-quarters majority, whereas such matters as the budget would require consensus. Making decisions based on consensus is one of the main characteristic features of the so-called "ASEAN way" of diplomacy, including the preference for informality and discretion (Feraru, 2015), the rule of non-interference into domestic affairs of other countries, non-use of force, respect for territorial integrity and sovereignty, as well as peaceful resolution of conflicts and disputes. ASEAN's attempts towards building consensus among its members has met with applause and criticism. On the one hand, the supporters of this idea point out that this approach facilitates the settlement of internal conflicts, and even shapes a regional identity (Naess, 2001). On the other hand, the contenders have highlighted that emphasis on consensus postpones the entire decision-making process and results in a weak organisation that is unable to convince reluctant members to concede (Feraru, 2015). Voices of discontent with the current approach of ASEAN have also appeared among some leaders from the Southeast Asia. Tran Dai Quang, the President of Vietnam between 2016 and 2018, underlined during his lecture in Singapore in 2016 that ASEAN should further reorganise its decision-making process in order to ensure greater adaptability in terms of dealing with complex issues (ASEAN Information Center, 2016). Moreover, the high level of distrust between the members of ASEAN and China may prove the principle of consensus to be ineffective and eventually lead to a stalemate, or even the collapse of a potential regime. Nevertheless, a closer look at consensus-based decision-making shows that in case of a deadlock, ASEAN usually recourses to bilateral negotiations in order to overcome discrepancies between the parties with opposing opinions. Such approach allows keeping and solving all possible animosities beyond ASEAN, as well as opening the door for negotiations concerning other matters. In other words, ASEAN frequently achieves consensus-based decisions thanks to intergovernmental consultation. In conclusion, the decision-making procedure proposed by the 
Convention on the Regulation of Antarctic Mineral Resource Activities that requires consensus in non-substantial matters might suit the claimants, since it follows the pattern developed by ASEAN, the organisation most of them are members of. By contrast, three-quarters majority in case of matters of substance would ensure faster progress in the most essential issues, whereas any disagreement could be solved through bilateral negotiations.

Secondly, the South China Sea has drawn the attention of states outside of the Southeast Asia. The U.S. considers the South China Sea as waters of high priority in its pursuit of its national interests in the Southeast Asia and a salient sign of its dedication to the idea of upholding the international law. Such perception of the South China Sea's role in its regional politics has been embodied in the United States' stance on the freedom of navigation operations and its persistent endorsement of the 2016 ruling of the Permanent Tribunal of Arbitration in the Hague. Washington has engaged in containing China from further unilateral attempts to dominate the South China Sea (Scobell, 2018) and hence, it has been forming the network of alliances in the region and beyond. Due to their ties with the U.S., such countries as Japan and more recently Australia have also become involved in curbing China, which has been demonstrated in joint military drills of the American, Japanese and Australian navies in the Philippine Sea in the second half of July 2020 (Greene, 2020). It is hard to imagine that such countries would not like to have any impact on the shape of a potential maritime regime of the South China Sea, even though it would be concerned only with environmental issues at least at its initial stage. States that do not belong to the Southeast Asia could become the observers of the decision-making commission without a voting right, they could voice their recommendations during meetings. Alternatively, those countries could appoint their own experts to the advisory institution. Any other form of engagement involving active participation in day-to-day matters of such maritime regime would most likely be accepted by some claimants. China would be especially reluctant to allow external parties to have a greater say in the matter, since it is rather well known that Beijing has been stressing the importance of limiting the influence of any entity not directly involved in the dispute, particularly this from outside of the South China Sea region. However, Vietnam and the Philippines have expressed their willingness to include external parties and discuss relevant 
issues multilaterally (Kao, Pearre and Firestone, 2012). Thus, introducing the observer status would provide the necessary compromise between claimants with opposing views.

Finally, if any maritime regime is to be established in the South China Sea, the question of the involvement of the Republic of China (Taiwan) needs to be addressed, since it is one of the six claimants of the Spratly Islands. Taiwan was removed from the United Nations (UN) and the UN Security Council in 1971 (Huang, 2003), and due to the fact that the UN membership is inextricably intervened with sovereignty (Charter of the United Nations, 1945, art. 3), Taiwan has not been regarded as a state on the international area ever since, even though it fulfils the criteria of statehood (Bartmann, 2008). Therefore, Taiwan's participation and membership in various international organisations has been limited. Yet, it still belongs to such organisations as the International Olympic Committee (IOC), Asia-Pacific Economic Cooperation (APEC), Asian Development Bank (ADB), Governmental Advisory Committee of the Internet Cooperation for Assigned Names and Numbers, and World Trade Organization (WTO) (Hickson, 2003). Taiwan's engagement in the abovementioned organisations has been made possible through the adoption of a different approach toward membership. In the IOC and APEC, Taiwan operates under the name of "Chinese Taipei", whereas WTO (2001) accepted Taiwan as the „Separate Customs Territory of Taiwan, Penghu, Kimmen and Matsu". Furthermore, Taiwan also belongs to the Commission for Conservation and Management of Highly Migratory Fish Stock in the Western and Central Pacific Ocean (Wang, 2001). It was feasible thanks to article 1(3) of the Agreement for the Implementation of the Provisions of the United Nations Convention on the Law of the Sea of 10 December, 1982, related to the Conservation and Management of Straddling Fish Stocks and Highly Migratory Fish Stocks (1995) stating that "[t]his Agreement applies mutatis mutandis to other fishing entities whose vessels fish on the high seas". Therefore, Taiwan was able to become a member of the Commission as the so-called "fishing entity" (Wang, 2001). Such organisations can play a role model for the potential participation of the Republic of China in a maritime regime in the South China Sea. Since the maritime regime discussed in this article is primarily concerned with environmental and economic matters, for instance fishery, the claimants could follow the example of the IOC, APEC, 
or the Commission for Conservation and Management of Highly Migratory Fish Stock and allow Taiwan to join the decision-making committee as "Chinese Taipei", or "fishing entity". Moreover, just like in the case of WTO, the statute of this committee could avoid using sovereignty as a condition potential members would have to meet.

KAMILA STASIAK, MA

Institute of the Middle and Far East

Faculty of International and Political Studies

Jagiellonian University

2a Oleandry Str., 30-036 Kraków

kamila.stasiak@doctoral.uj.edu.pl

\section{Bibliography}

Agreed Measures for the Conservation of Antarctic Fauna and Flora. (1962). Retrieved from: https://www.peacepalacelibrary.nl/ebooks/files/AgreedMeasuresfortheConservationofAntarcticFaunaandFlora.pdf.

Agreement for the Implementation of the Provisions of the United Nations Convention on the Law of the Sea of 10 December 1982 relating to the Conservation and Management of Straddling Fish Stocks and Highly Migratory Fish Stocks. (1995, 4 August). Retrieved from: https://www.un.org/Depts/los/convention_agreements/ texts/fish_stocks_agreement/CONF164_37.htm.

ASEAN Centre for Biodiversity. (2010). Turtle Islands Heritage Protected Area. Retrieved from: http://chm.aseanbiodiversity.org/index.php?option=com_content \&view $=$ article\&id $=137 \&$ Itemid $=223$.

ASEAN Information Center. (2016, 16 December). ASEAN needs a better decision-making process. Retrieved from: http://www.aseanthai.net/english/ewt_news. php?nid=1684\&filename $=$ index.

Asia Maritime Transparency Initiative. (n.d.). Occupation and Island Building. Retrieved from: https://amti.csis.org/island-tracker/.

Asia Maritime Transparency Initiative. (2017, 13 September). Blueprint for Fisheries Management and Environmental Cooperation in the South China Sea. Retrieved from: https://amti.csis.org/coc-blueprint-fisheries-environment/.

Bartmann, B. (2008). Between De Jure and De Facto Statehood: Revisiting the Status of Taiwan. Island Studies Journal, 3(1), 113-128.

Beckman, R.C. (2009). Legal regimes for cooperation in the South China Sea. In: S. Bateman, R. Emmers (eds.). Security and International Politics in the South China Sea: Towards a co-operative management regime (222-235). London: Routledge. 
Beckman, R., Townsend-Gault, I., Schofield, C., Daverport, T., Bernard, L. (eds.). (2013). Beyond Territorial Disputes in the South China Sea: Legal Frameworks for the Joint Development of Hydrocarbon Resources. Cheltenham: Edward Elgar Publishing.

Buszyński, L. (2012). The South China Sea: Oil, Maritime Claims, and U.S.-China Strategic Rivalry. The Washington Quarterly, 35(2), 139-156.

Buszyński, L., Sazlan, I. (2007). Maritime Claims and Energy Cooperation in the South China Sea. Contemporary Southeast Asia, 29(1), 143-171.

Chansoria, M., Palma-Robles, A.M. (2015). Arbitrating Conflict in the South China Sea: The Case of China and the Philippines. Centre for Land Warfare Studies Journal, 21-43.

Charter of the United Nations. (1946, 26 June). Retrieved from: https://www.un.org/en/ sections/un-charter/un-charter-full-text/.

Cohen, H.K. (ed.). (2002). Handbook of the Antarctic Treaty System. Retrieved from: https://2009-2017.state.gov/e/oes/rls/rpts/ant/index.htm.

Convention on the Conservation of Antarctic Marine Living Resources. (1980, 20 May). Retrieved from: https://ec.europa.eu/world/agreements/prepareCreateTreatiesWorkspace/treatiesGeneralData.do? $\mathrm{ste} p=0 \&$ redirect $=$ true\&treatyId $=501$.

Convention for the Conservation of Antarctic Seals. (1972, 1 June). Retrieved from: https://2009-2017.state.gov/documents/organization/15280.pdf.

Convention on the Regulation of Antarctic Mineral Resource Activities. (1988, 25 November). Retrieved from: https://www.treaties.mfat.govt.nz/search/details/t/1704.

Dutton, P. (2011). Three Disputes and Three Objectives-China and the South China Sea. Naval War College Review, 64(4), 42-67.

Feraru, A.S. (2015). ASEAN Decision-Making Process: Before and after the ASEAN Charter. Asian Development Policy Review, 4(1), 26-41.

Governor of Svalbard. (n.d.). Nature Conservation Areas. Retrieved from: https:// www.sysselmannen.no/en/the-governor-of-svalbard/environmental-protection/ nature-conservation-areas/.

Góralczyk, B. (2018). Wielki renesans. Chińska transformacja i jej konsekwencje. Warszawa: Wydawnictwo Akademickie Dialog.

Greene, A. (2020, 22 July). Australia joins United States and Japan in naval exercise as concerns grow over China. $A B C$ News. Retrieved from: https://www.abc.net.au/news/ 2020-07-22/australia-joint-show-strength-united-states-japan-china-concerns/ 12479144.

Huang, E.T. (2003). Taiwan's Status in a Changing World: United Nations Representation and Membership for Taiwan. Annual Survey of International \& Comparative Law, 9(1), 55-99.

Huang, J., Jagtiani, S. (2015). Introduction: Unknotting Tangled Lines in the South China Sea Dispute. In: J. Huang, A. Billo (eds.), Territorial Disputes in the South China Sea: Navigating Rough Waters (1-12). London: Palgrave Macmillan.

Kao, S. (2015). International Practices on the Management of Fishery Resources: Lessons Learnt for the South China Sea. Journal of International Wildlife Law \& Policy, 18(2), 165-183.

Kao, S., Pearre, N.S. (2018). Regional Cooperation in the Post-South China Sea Arbitration Era: Potential Mechanism and Cooperative Areas. Coastal Management, 46(3), 1-20. 
Kao, S., Pearre, N. S., Firestone, J. (2012). Regional Cooperation in the South China Sea: Analysis of Existing Practices and Prospects. Ocean Development \& International Law, 43(3), 283-295.

Kaplan, R.D. (2011, August 15). The South China Sea Is the Future of Conflict. Foreign Policy. Retrieved from: https://foreignpolicy.com/2011/08/15/the-south-china-sea -is-the-future-of-conflict/.

Khemakorn, P. (2006). Sustainable Management of Pelagic Fisheries in the South China Sea Region. New York: United Nations - The Nippon Foundation. Retrieved from: https://www.un.org/depts/los/nippon/unnff_programme_home/fellows_pages/ fellows_papers/khemakorn_0607_thailand.pdf.

Kraska, J. (2019). The Exclusive Economic Zone and food security for developing coastal states in the South China Sea. In: T.T. Tran, J.B. Welfield, T.T. Le (eds.), Building a Normative Order in the South China Sea (116-131). Cheltenham: Edward Elgar Publishing.

MacLaughlin, R., Nasu, H. (2015). The Law's Potential to Break - Rather Than Entrench - the South China Sea Deadlock?. Journal of Conflict and Security Law, 21(2), 1-33.

Marszałek-Kawa, J., Dmochowski, T. (red.). (2018). Rozważania o kierunkach współczesnej polityki Chin. Toruń: Wydawnictwo Adam Marszałek.

Meierding, E. (2017). Joint Development in the South China Sea: Exploring the Prospects of Oil and Gas Cooperation Between Rivals. Energy Research \& Social Science, 24, 65-70.

Misund, O.A., Heggland, K., Skogseth, R., Falck, E., Gjøsæter, H., Sundet, J., Watne, J., Lønne, O.J. (2016). Norwegian Fisheries in the Svalbard Zone since 1980. Regulations, Profitability and Warming Waters Affect Landings. Polar Science, 10(3), 312-322.

Mission of the People's Republic of China to the European Union. (2016, 20 June). China Has Indisputable Sovereignty over the South China Sea Islands. Retrieved from: http://www.chinamission.be/eng/more/SouthChinaSeaIssue160420001/t1373561. htm.

Mitchell, M.D. (2016). The South China Sea: A Geopolitical Analysis. Journal of Geography and Geology, 3(8), 14-25.

Naess, T. (2001). Environmental cooperation around the South China Sea: the experience of the South China Sea Workshops and the United Nations Environment Programme's Strategic Action Programme. The Pacific Review, 14(4), 553-573.

Nguyen Dang, T. (2012). Fisheries Co-operation in the South China Sea and the (Ir) relevance of the Sovereignty Question. Asian Journal of International Law, 2, 59-88.

Ohnesorge, H.W. (2016). A Sea of Troubles: International Law and the Spitsbergen Plus Approach to Conflict Management in the South China Sea. In: E. Fels, T. M. Vu (eds.), Power Politics in Asia's Contested Waters: Territorial Disputes in the South China Sea (25-55), Cham: Springer.

Peace Palace Library. (n.d.). South China Sea Territorial Disputes (continued). Retrieved from: https://www.peacepalacelibrary.nl/south-china-sea-territorial-disputes -continued/.

Permanent Court of Arbitration. (2013). The South China Sea Arbitration (The Republic of Philippines v. The People's Republic of China). Retrieved from: https://pca-cpa. org/en/cases/7/. 
Pietrasiak, M. (2016). Konflikt o archipelagi na Morzu Południowochińskim i perspektywy jego uregulowania. In: T. Domański (ed.), Międzynarodowe studia polityczne i kulturowe wobec wyzwań współczesności (261-274). Łódź: Wydawnictwo Uniwersytetu Łódzkiego.

Protocol on Environmental Protection to the Antarctic Treaty. (1991, 4 October). Retrieved from: https://www.ats.aq/e/protocol.html.

Scobell, A. (2018). The South China Sea and U.S.-China Rivalry. Political Science Quarterly, 133(2), 199-224.

Scott, S.V. (2018). What lessons does the Antarctic Treaty System offer for the future of peaceful relations in the South China Sea?. Marine Policy, 87, 295-300.

Secretariat of the Antarctic Treaty. (n.d.). The Committee for Environmental Protection. Retrieved from: https://www.ats.aq/e/committee.html.

Storey, I. (2008). Trouble and Strife in the South China Sea Part II: The Philippines and China. China Brief, 8(9). Retrieved from: https://jamestown.org/program/ trouble-and-strife-in-the-south-china-sea-part-ii-the-philippines-and-china/.

Svalbard Environmental Protection Act. (2001, 15 June). Retrieved from: https://www. regjeringen.no/en/dokumenter/svalbard-environmental-protection-act/id173945/.

The Philippines v. The People's Republic of China. (Final Award) (Permanent Court of Arbitration, case No. 2013-19, 2016, 12 July). Retrieved from: https://docs.pca-cpa. org/2016/07/PH-CN-20160712-Award.pdf.

Treaty between Norway, The United States of America, Denmark, France, Italy, Japan, the Netherlands, Great Britain and Ireland and the British overseas Dominions and Sweden concerning Spitsbergen. (1920, 9 February). Retrieved from: http://library. arcticportal.org/1909/1/The_Svalbard_Treaty_9ssFy.pdf.

Turcsányi, R.Q. (2018). Chinese Assertiveness in the South China Sea. Power Sources, Domestic Politics, and Reactive Foreign Policy. Cham: Springer.

UNESCO. (n.d.). Turtle Islands Wildlife Sanctuary. Retrieved from: https://whc.unesco. org/en/tentativelists/6008/.

United Nations Convention on the Law of the Sea. (1982, 10 December). Retrieved from: https://www.un.org/Depts/los/convention_agreements/texts/unclos/UNCLOS-TOC.htm.

U.S. Energy Information Agency. (2013, 7 February). South China Sea. Retrieved from: https://www.eia.gov/international/analysis/regions-of-interest/South_China_Sea.

Valencia, M.J., Van Dyke, J.M., Ludwig, N.A. (1999). Sharing the Resources of the South China Sea. Honolulu: University of Hawaii Press.

Van Dyke, J.M., Broder, S.P. (2014). Regional Maritime Cooperation in the South China Sea: COBSEA and PEMSEA. In: Y. Song, K. Zou (eds.), Major Law and Policy Issues in the South China Sea: European and American Perspectives (17-24). Farnham: Ashgate.

Vu, H.D. (2014). Disputes between Vietnam and China in the South China Sea: A Legal Analysis. In: M. Hiebert, P. Nguyen, G.B. Poling (eds.), Perspectives on the South China Sea Dispute: Diplomatic, Security and Legal Dimensions of the Dispute (35-44). Lanham: Rowman and Littlefield.

Wang, K. (2001). Bridge over Troubled Waters: Fisheries Cooperation as a Resolution to the South China Sea conflicts. The Pacific Review, 14(4), 531-551. 
Wang, Q., Cui, H., Zhang, S., Hu. D. (2009). Water Transports through the Four Main Straits around the South China Sea. Chinese Journal of Oceanology and Limnology, 27(2), 229-236.

Weissman, M. (2012). The East Asia Peace: Conflict Prevention and Informal Peacebuilding. Basingstoke: Palgrave Macmillan.

World Trade Organisation. (2001, 18 September). WTO successfully concludes negotiations on entry of the Separate Customs Territory of Taiwan, Penghu, Kinmen and Matsu. Retrieved from: https://www.wto.org/english/news_e/pres01_e/pr244_e.htm.

Zhang, H. (2018). Fisheries Cooperation in the South China Sea: Evaluating the Options. Marine Policy, 89, 67-76.

Zhang, H. (2019). The Duty of Cooperation in Semi-Enclosed Seas: Exploring the Way Forward for the South China Sea, In: K. Zou (ed.). Maritime Cooperation in Semi-Enclosed Seas: Asian and European Experiences (30-50), Leiden: Brill/Nijhoff.

Zhong, H., White, M. (2017). South China Sea: Its Importance for Shipping, Trade, Energy and Fisheries. Asia-Pacific Journal of Ocean Law and Policy, 2(1), 9-24.

Zou, K. (2006). Joint Development in the South China Sea: A New Approach. The International Journal of Marine and Coastal Law, 21(1), 83-109.

Zou, K. (2014). Bringing the South Pole to the South China Sea: Towards the Establishment of an International Regime for Peace and Security. In: Y. Song, K. Zou (eds.), Major Law and Policy Issues in the South China Sea: European and American Perspectives (137-159). Farnham: Ashgate. 